were more limpid than young ones. Only their outlines were readily observable, while the inner parts of the spindle were optically almost empty except for small cylindrical bodies which by their high refractability, particularly in dark-ground illumination, revealed their nature as bacterial spores (Figs. $7,8)$. This was confirmed by their capacity for retaining the fuchsin stain on treatment with acid alcohol.

Later on, transition stages in spore formation were also found in colonies in which the filamentous cellunits were still readily visible. Not all of these formed spores. The spores were usually close to the middle. Their shapes varied from almost oval to, more commonly, cylindrical. Their width was about $1 \cdot 5 \mu$, their length $5-7 \mu$.

These spores are no doubt the reproductive units responsible for the development of Fasciculus from completely dry soil. Their germination could, unfortunately, not be observed because of the failure to cultivate the organism and to separate it from other organisms. It is very peculiar that the individual cell margins vanish almost completely during spore formation, although the whole colony continues to swim about, and its outlines remain clearly visible (Figs. 7, 8)

The structure or nature of the filaments composing the large spindles is also different from that of most bacteria. As already mentioned, optically the organism is fainter than other organisms. In darkground illumination it becomes more distinct, and the outlines of the filaments show more clearly than, for example, the outer membranes of Myxobacteria.

These filaments are believed to be cells. They are $2 \mu$ across and about $50-100 \mu$ in length. They stain with fuchsin and methylene blue, but, in accordance with their low refractability, not strongly. They do not keep the Gram stain, contrary to most bacterial spore-formers. Only the membranes of the spores were stained; they were also more deeply coloured when treated with the Ziehl-Neelsen technique.

The mode of locomotion, rotating and swimming freely through the water, recalled that of flagellates or large bacteria. I did not succeed in demonstrating flagella with the help of Loeffler's technique, of Deflandre's nigrosin method, or dark-ground illumination. Quick drying on fat-free cover-slips or fixing with osmium tetroxide vapour or iodine or Schaudinn's mercury chloride fixation did not make any difference. But I believe this failure was somehow due to inadequate technique, and do not doubt that flagella do exist, since the impression of the swimming movement scarcely allows of any other interpretation.

If this were so, we would have another example of an 'organized' bacterial colony as earlier described for Vannielia aggregata ${ }^{1}$. This belongs to the Athiorhodaceae, a family where colony formation had not been known to exist. There, also, many cells are aggregated to constitute a composite unit driven through the water and rotating by co-operation of the flagella; but here the similarity ends. While in Fasciculus the units of the colony are long, tube-like structures, those of Vannielia are rod-shaped cells radiating from the centre of the colony. Another motile bacterial colony is that of Chlorochromatium aggregatum, where again the arrangement of the individual components is quite different. Only one relatively large, central rod possesses a flagellum responsible for the movement of the colony, while the yellowish green small outer cells only adhere to the actively swimming central rod.

It is not possible to include Fasciculus in one of the taxonomic groups of the Bacteria. Very long, tubiform cells are known in Lineola ${ }^{2}$, but this genus does not form colonies, and the production of spores and the appearance of the cells are different. In Lineola droplets and other contents are visible under the microscope, and the staining with various dyes is quite normal for a bacterium. Fasciculus is much less stainable and the inner part of the cell is almost empty optically. Moreover, the ecological conditions in which the new organism thrives seem to be peculiar. A better insight into its nature could only be obtained by cultivation. I will gladly supply portions of dry soil to bacteriologists who are interested in this creature.

'Pringsheim, E. G., J. Gen. Microbiol., 13, 285 (1955). 'Pringsheim, E. G., J. Gen. Microbiol., 4, 198 (1950).

\title{
BIOLOGICAL PROBLEMS ARISING FROM THE CONTROL OF PESTS AND DISEASES
}

\begin{abstract}
$\mathrm{T}$ HE Institute of Biology has developed a technique for eutting through the hedges which grow up between fields of knowledge as biology undergoes speciation into ever new branches. One of the methods of doing this used by the Institute is to arrange symposia for which the subjects and speakers are ehosen with considerable care. Thus, before even a word was spoken in the Royal Geographical Society's well-filled lecture hall on October 1, a look around indicated a successful meeting, for there were many well-known specialists in different fields who seldom previously have found themselves sitting in one room. The subject of this two-day symposium, namely, "Biological Problems arising from the Control of Pests and Diseases", is one of wide and topical interest. The speakers, including those who contributed to several stimulating discussions, were economic entomologists and botanists, medical men
\end{abstract}

and veterinarians, psychologists and humanitarians, in addition to academic biologists.

The symposium was arranged in four sessions, each under a different chairman. This arrangement divided the subject rathor broadly into problems associated with arable agriculture, animal husbandry, human disease and health, but the matter presented tended to transcend any grouping. It became apparent that there are many connecting threads between, for example, the drug resistance developed by bacteria and the stimulation to growth of animals consequent on small additions of antibiotics to their diet, that the consequences of malaria control react quickly on the ecological problems of crop and animal pests through ehanges in human needs, and that too rigid a control of mental deficieney might have a retarding influence on science and art. Several facets of the discussion pointed to the human being 
as the greatest pest of all. One speaker was bold enough to suggest that every pest and disease worthy of the name was, in fact, a human artefact, and given time he might convert almost every surviving wild organism into a pest. Although some would scarcely go so far, there were several expressions on the value of maintaining at least some areas of the world in a natural or semi-natural state. Thus, in the problem of controlling agricultural pests, reference was made to Elton's plea for ecological diversity if only to provide reservoirs of the predators and parasites of pests.

The stage was set by Mr. F. C. Bawden, ehairman of the first session, who directed attention to the unexpected and sometimes undesirable results which follow action against any particular pest or disease of importance in agriculture. The control of one may let in another. He was unable, however, to quote any case where the secondary trouble had resulted in greater economic loss than the primary one, and therefore concluded that on the whole there was always a net gain. This theme was taken up by Mr. A. H. Strickland, of the Ministry of Agriculture and Fisheries Plant Pathology Laboratory at Harpenden. He provided a valuable assessment of recent work with insecticides, but neglected the classical work of biological control because it was well covered in a recent survey by Prof. G. C. Varley in a paper before the Royal Society of Arts. He instanced cases where eradication of species had been attempted, such as the Colorado beetle from Europe and the Mediterranean fruit fly, which has twice boen introduced into and eradicated from the United States; and he pointed out that in Britain no less than a fifth of the acreage of root and some vegetable crops is treated annually with insecticides as a routine measure. To those-including many farmers-who deplore the very widescale use of insecticides and herbicides as an excuse for sloppy husbandry, $\mathrm{Mr}$. Strickland had some encouraging words about recent studies of the manipulative possibilities such as physical control of the soil by rotovation, and the adjustment of spacing in sowing and planting which can render crops unattractive to pests or stimulate the crop to grow away.

Dr. T. J. Martin, of the Research Station, Long Ashton, dealt with the direct risks to man arising from the fact that fifteen out of the forty-two or so insecticides and fungicides in common usage are in the highly toxic category. Study of the risks to spray operators led to the Agriculture (Poisonous Substances) Regulations of 1956, and, in spite of some accidents, it seems that the risks to the consumers of crops which have been subjected to a variety of toxic sprays are under control, at least in Great Britain. Discussion revealed that, with the exception of arsenic, for which there is a legal tolerance, the use of any spray on the land in Britain is entirely at the discretion of the manufacturer and the farmer. Neither Dr. Martin nor any other speaker was in a position to deal with the influence of toxic materials on wild plants and animals or on game, although these largely unknown but important influences were doubtless in mind. It is abundantly clear that there is to-dry a heavy responsibility falling on entomologists and botanists to obtain and interpret information on the selectivity and tolerance-levels of these chemicals, in order to give advice to manufacturers and users on formulations, dosages and methods of application in such a way that indiscriminate slaughter can itself be brought under control.
Mr. F. G. H. Lupton, of the Plant Breeding Institute at Cambridge, set a different note by describing some striking successes in controlling diseases through genetical resistance or tolerance; but he mentioned that all too often the plant breeder is called in only when other methods have failed. Among other examples he described the ding-dong race which was started in 1912 by Sir Roland Biffen and is still in full cry between the genes of newly evolving races of the rust fungus and resistant genes of wheat sorted out by plant breeders. The series Marquis - Ceres - Thatcher - Pilot - Selkirk have so far kept alive the economy of the Great Plains, but the race is still neck-and-neck.

The second session introduced several problems from overseas. Thus, Mr. M. Crawford, of the Commonwealth Bureau of Animal Health at Weybridge, emphasized that eradication of a killing disease of livestock, such as rinderpest, could lead to harmful effects from over-population, over-grazing and mainutrition if achieved among peoples who regard stock as a social or religious asset without economic controls. Such experience was referred to also by Mr. W. H. Potts, formerly of the Colonial Service, with reference to the control of tsetse flies and trypanosomiasis. He was not, however, prepared to support the tendency in recent years to hail the tsetse fly as the preserver of the African soil from destruction by man. This theme, like the earlier one on controlling agricultural pests, led to discussion on the advantages or disadvantages of ecological diversity as a background for the economie use of land. There is, for example, evidence that in the African semi-arid bush the broad spectrum of wild indigenous fauna, fully adapted to living off the indigenous vegetation at all levels, could, under proper systems of management and annual cropping, produce human food little if any less than is produced by the narrow spectrum of exotic domestic stock. At least there is a case for spending money to explore such possibilities in selected areas, rather than to spend all that is available on the blind eradication of wild-life and tsetse flies.

The control of human diseases in tropical areas was the subject of two contributions, by Prof. T. Davey, of the School of Tropical Medicine at Liverpool, and Sir Gordon Covell. The latter mentioned that during the World Health Organization campaign there were two hundred teams working in India, each of which looked after one million people. Despite such campaigns, the Organization's figures show that the annual loss from malaria is still a vast one. The improvement of physique and of work undertaken by persons in malarial areas is marked, following control. There is normally some resistance to malaria, but this resistance is only local, so that an influx of persons from another district may result in severe outbreaks. Although Sir Gordon did not say so, this, of course, was known in England during past centuries, when it was noted that a wife from outside taken into such malarial areas as the Fens or Hundred of Hoo was liable to die within a short time, whereas the locals were in balance with their disease.

Prof. Davey dealt more with the sociological problems expected as a result of the control of such diseases as malaria, and pointed out that nowadays in India the excess of births over deaths is some 15,000 a day. In discussing birth control as the biological remedy, he mentioned that certain classes are more amenable to birth-control methods than others, and that in a low-level subsistence type of 
society every additional member of the family gives another worker, and so a better chance for survival. Where social conditions are better, each additional mouth is a liability rather than an asset. Thus the lower the subsistence-level the greater the birth-rate tends to be.

Dr. E. Slater, of the National Hospital for Nervous Diseases, raised some interesting points about the geneties of mental disease, and pointed out that the discovery of new methods of treatment enabled certain diseases which are transmitted genetically as dominants to increase their proportion in the popula tion. This was simply done by overeoming the biological disadvantages which these dominant genes will contain, provided no treatment is given. Among the interesting points he made were that the manicdepressive type of patient is met with ten times as frequently among scientists as among the rest of the population. This may be a question of either cause or effect. Schizophrenies are found particularly among artists, and in these patients fertility is only 70 per cent that of normal. There is a possibility that this disease may be associated with some genetic advantage. The question whether certain types of mental defective should be sterilized is difficult because it is possible that workers in, for example, the artistic and scientific fields, may show improved output over the normal if they have some minor degree of mental disease.

The problems which arise from drug-resistance in bacteria were treated in a sparkling contribution by Dr. Mary Barber, of the Postgraduate Medical School, London. She pointed out that not all bacteria have taken the massive attack by antibiotics in clinical medicine lying down; in the case of Staphylococcus diogenes, drug-resistant strains are now the major bacterial scourge in hospitals all over the world. Resistant strains of bacteria may be drug-tolerant or drug-destroying, and in certain cases may even become drug-dependent. Evidence points to the resistance being genetic rather than adaptive, and that penicillin, for example, has caused a prodigious evolution in the population structure of Staphylococcus by simple selection. Those strains carrying resistant genes which formerly were present in a tiny proportion have now increased to 60 or 70 per cent of the population in most hospitals. The same principle applies in the case of insect resistance to the new synthetic insecticides, as explained by Dr. J. R. Busvine, of the London School of Hygiene and Tropical Medicine. In more than a hundred harmful insects resistant strains have occurred, and in some cases the inheritance of the resistant trait has been shown to be of a normal Mendelian type. Whether the trait is 'physiological', which is immune to the poison, or 'behaviouristic', which manages to avoid it, its emergence seems to constitute greatly accelerated evolution on essentially Darwinian lines. Dr. R. Brande, from the National Institute for Research in Dairying at Shinfield, spoke on the recent experiments which show that very small amounts of antibiotics added to the diet of domestic animals increase growth-rate up to 10 per cent and the efficiency of food conversion by from 3 to 5 per cent. He explained that economic advantage of this phenomenon is being taken now on quite a large scale in the United States, although the biological reasons for it are as yet in the realm of conjecture.

The last contribution to the symposium was by Dr. G. C. L. Bertram, from St. John's College, Cambridge, who spoke of 'ethical' or deliberate selection in mankind as having supplanted natural selection. He sketched the sequence of events which led to a doubling of the human population in the past eighty years or so, and the probability that it will double again during the next forty years-European dominance, followed by reduction of strife, the development of hygiene, and the control of biological competitors. Human compassion has led to death control, and now is the time for a great extension of birth control as a further expression of the freedom of choice by the individual. Having accepted Sir James Gray's concluding thought expressed in his presidential address at the York meeting of the British Association that man now has the intelligence and the knowledge to control his own destiny, the question has still to be answered what that destiny is. In a cynical moment, Dr. Bertram compared modern man with a drunkard riding a runaway horse, whereas Dr. A. S. Parkes, who guided this final session from the chair, expressed the hope that our freedom of choice would never become so wide that we would ourselves have to decide whether or not to be born.

E. B. WORThINGTON

\title{
DARWIN'S ILLNESS
}

\author{
By Prof. S. ADLER, O.B.E., F.R.S. \\ Department of Parasitology, Hebrew University, Jerusalem
}

$\mathrm{D}$ ARWIN'S illness, which practically amounted to forty years of invalidism, has given rise to considerable speculation. The doctors who treated him could find no physical explanation for his distressing symptoms and apparently concluded that he was a hypochondriac.

Darwin, whose sufferings were very real, complained in a letter to Hooker "many of my friends I believe think me a hypochondriac". Commenting on this, the late Sir Arthur Keith", in his book "Darwin Revealed", remarks emphatically "Darwin was a hypochondriac, a very real one...".

$\mathrm{Hubble}^{2}$ states that "it is apparent that his illness bears the unmistakeable marks of an emotional disorder" and adds, "his psychoneurosis may be regarded as an adaptation to his environment which nourished and protected in the highest degree his uncommon genius". This author ${ }^{3}$ justifies his diagnosis on the basis of Darwin's farnily history. $\mathrm{He}$ rightly points out that Darwin's wife was an exceptionally devoted nurse and his son showed a tendency to hypochondria. It may, on the other hand, be argued that the above qualities were acquired and not inherent; chronic invalidism in the head of a family, whatever its cause, has psychological consequences and may well induce in the mother a strong tendency to nurse and protect, and in the younger members of the family an exaggerated fear of disease. 